\section{EREM 76/2}

Journal of Environmental Research, Engineering and Management Vol. 76 / No. 2 / 2020 pp. 22-33

DOI 10.5755/j01.erem.76.2.20916

\section{Mapping the Mean Annual River Runoff in the Ukrainian Carpathian Region}

\begin{tabular}{l|l}
\hline Received 2018/06 & Accepted after revision 2020/06
\end{tabular}

http://dx.doi.org/10.5755/j01.erem.76.2.20916

\title{
Mapping the Mean Annual River Runoff in the Ukrainian Carpathian Region
}

\section{Oleksandr Obodovskyi, Olga Lukianets*, Oksana Konovalenko, Valeriy Mykhaylenko}

Taras Shevchenko National University of Kyiv, 2-A, Glushkov Prospekt, Kyiv, SMP680, Ukraine

\section{*Corresponding author: luko15_06@ukr.net}

The paper presents the spatial distribution of the mean annual river runoff in the Ukrainian Carpathians in the form of a map. The methodological approaches concerning the river runoff mapping and the technological stages of map creation by applying the geographic information system (GIS) analytical functions are considered. The accuracy assessment of the calculation of the mean annual river runoff water based on the data from the hydrometric stations for the whole observation period was performed. The mapping reliability of the mean annual runoff and their territorial variability over the main basins in the Ukrainian Carpathians are analysed.

Keywords: rivers of the Ukrainian Carpathians, analytical functions of GIS, spatial distribution, mean annual river runoff, water resources.

\section{Introduction}

Maps of runoff give not only an idea about the spacetime variability of river runoff distribution over the studied area but also the quantitative information on a spatial variability, seasonality and regularity of river runoff. Therefore, maps are widely used for hydrological studies on the regime of individual rivers or river systems, in hydrological modelling and forecasting, as well as in construction and hydraulic calculations. The main purpose of this paper is to present the modern map of the mean annual river runoff in the Ukrainian Carpathians (the basins of Tisza, Prut and Dniester rivers), its generalisation for designing the stream power hydro-energy potential of rivers, even those unstudied. Of particular interest are such maps when a river runoff locating is required from hydrologically unstudied river basins. The obtained results can be used aiming at elaborating the usage of water resources for designing of hydroelectric power plant placement in Ukraine. 


\section{The methodology of the mean annual river runoff mapping}

Since the very beginning, the detailed mapping of all main basins located within the Ukrainian Carpathians was encompassed based on observational data.

The majority of maps cover either separate basins or the ones with long series for mapping the runoff characteristics. Many scientists have been engaged in mapping the average annual river runoff. The most significant researches of the past were presented by Zaykov, Kocherin and Sokolovsky who are recognised as the founders of river flow mapping in the Soviet Union (Zaykov et al., 1937; Kocherin, 1932; Sokolovskiy, 1968). Ukrainian scientists applied such methodology for developing runoff maps for Ukraine and for rivers of the Carpathian region. The special attention was demonstrated by the scientists of the Ukrainian Hydrometeorological Institute who created the map of the mean annual river runoff as a part of the National Atlas of Ukraine in 2007 (Paton et al., 2007). This map covered the observation period from 1950 to 2000. Establishing of the Geographic Information System (GIS) technique allows performing various types of interpolations that made the issue of GIS mapping of the river runoff actual. Ukrainian hydrologists put the river runoff maps on the GIS platform for the entire territory of Ukraine (Horbachova, 2010) as well as for the individual river basins (Konovalenko et al., 2012). GIS mapping of the runoff features is also the subject of study by Russian scientists (Denisova et al., 2009; Klimenko, 2009; Melnikova, 2004). As of now, the rivers runoff maps on a GIS platform have found wide use in most countries (Mean annual Surface Runoff 1950-2000; Global Data Explorer).

The rivers runoff is the ultimate result of water balance and the main component of the river hydrological regime. It determines their water-bearing and rate of water stream-flows (Klibyshev et al., 1970; Komlev, 2002). Changes in climatic (or weather) circumstances affect active factors, such as precipitation and evaporation, and the latter, interacting with river basins, largely form river runoff. Therefore, the size and characteristics of the river drainage basin, the depth of the groundwater and atmospheric conditions are important to the GIS mapping technique.
Certain regularities, including both latitudinal and altitudinal zoning, cause a change in the runoff of the territory. Therefore, besides climate, the size, characteristics and specifics of the river drainage basin and depth of underground waters are important. For example, with all other conditions being equal, two basins located at different altitudes will differ in the runoff volume. The runoff of the river basin at a higher altitude and, normally, with higher precipitation and lower evaporation will be more abundant (Doganovskiy et al., 2011). With prolonged long-term observations, the value of the average mean annual river runoff may become unstable because the considered period may coincide with the periods of only increased or only lower annual river runoff. Therefore, to obtain a stable value of the mean annual river runoff, a series of a certain length that includes periods of high and low water content in the rivers is necessary.

To compare the estimates of the accuracy design of the mean annual river runoff water for different rivers, the concept of the relative value of the standard deviation (SD) is introduced. This is expressed in equation (1):

$$
\sigma_{Q_{n}}= \pm \frac{100 \cdot C v}{\sqrt{n}}
$$

Where: $C_{V}$ - coefficient of variation of annual mean runoff value series for $n$ years.

Unlike the values of the average SD that characterise the fluctuations of the water runoff of individual rivers, the coefficient of variation allows comparing the runoff of all rivers according to their variability (Doganovskiy et al., 2011; Luchsheva, 1976).

For mapping of the mean annual river runoff, it is necessary to represent the river runoff in a value associated with a catchment area-specific discharge $\left(\mathrm{dm}^{3} \cdot \mathrm{s}^{-1} \cdot \mathrm{km}^{-2}\right)$ and the depth of runoff $(\mathrm{Y}, \mathrm{mm})$ (Ven Te Chow et al., 1988; Klibyshev et al., 1970).

Mapping of hydrological characteristics that do not depend on the size of the catchment area is based on the assumption of their smooth changes over the territory in line with the distribution of climate (rainfall, evaporation) and other physical and geographical factors. The feature of mapping the hydrological characteristic lies in the fact that the values illustrated on the map 
are attributed not to the point of measurement (as in mapping the climatic characteristic), but to the entire catchment area as a whole. It depends upon the fact that the water river runoff as measured at the hydrological gauging section is the mean water runoff from the whole river basin. Values of the depth of water runoff or specific discharge are attributed to conventional points, namely, to the centre of gravity (centroid) of the river catchment basin (Ven Te Chow et al., 1988).

The mean annual river runoff maps are created usually for the closed river basins. When drawing a map, the river runoff data from small catchment areas are not plotted on the map, which means that the annual river runoff is largely determined by the azonal factors. What is more, when mapping, the materials of hydrometric observations along the major rivers that usually flow along from the several geographic areas are neglected. The mean annual river runoff for both small and large river catchment areas may serve only for the control over the mapping reliability (Doganovskiy et al., 2011).

The maps of the mean annual precipitation and evaporation may also be used for determination of the water balance of the catchment area and accuracy assessment of the mean annual river runoff.

Thus, when mapping, the values of the mean annual river runoff are attributed to the centre of gravity of a basin, followed by interpolation between them. The interpolation in mountainous areas is performed taking into account a relief of the terrain and a relationship between the mean annual river runoff and the mean elevation of their catchment areas. At the same time, one can consider other morphometric and hydrographic characteristics.

\section{Results and Discussion}

\section{Creating and correspondence with empirical data of the current (contemporary) map of the mean annual river runoff of the Ukrainian Carpathian}

Accuracy assessment determination of the mean annual river runoff

The map of the mean annual river runoff of the Ukrainian Carpathians was made taking into account the above information.

The input data obtained for the mean annual river runoff from the hydrometric stations located on the rivers (within borders of Ukraine) are given in Table 1. To compare the accuracy and reliability of the mean annual river runoff design, the relative SD (\%) was calculated using the equation (1) and is presented in Table 1. A series of observations of the average

Table 1. Accuracy of the mean river runoff determination in the Ukrainian Carpathians

\begin{tabular}{|c|c|c|c|c|c|c|c|}
\hline River & Hydrological gauge & 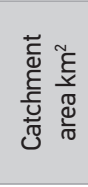 & 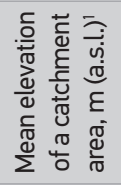 & 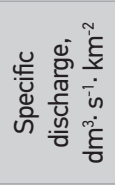 & 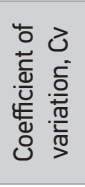 & 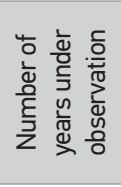 & 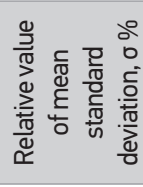 \\
\hline \multicolumn{8}{|c|}{ The Tisza basin } \\
\hline Tisza & Rakhiv & 1,070 & 1,100 & 24.0 & 0.21 & 66 & 2.6 \\
\hline Bila Tisza & Lugy & 189 & 1,200 & 27.1 & 0.21 & 58 & 2.8 \\
\hline Tisza & Vylok & 9,140 & & 22.7 & 0.24 & 59 & 3.1 \\
\hline Chorna Tisza & Yasynia & 194 & 1,000 & 24.9 & 0.26 & 57 & 3.4 \\
\hline Kosivska & Kosivska Polyana & 122 & 1,060 & 37.9 & 0.22 & 50 & 3.1 \\
\hline Teresva & Ust-Chorna & 572 & 1,100 & 32.1 & 0.25 & 63 & 3.1 \\
\hline Rika & Verkhniy Bystryi & 165 & 920 & 25.0 & 0.26 & 55 & 3.5 \\
\hline Borzhava & Dovge & 408 & 620 & 27.1 & 0.29 & 66 & 3.6 \\
\hline Studenyi & Nyzhniy Studenyi & 25 & 800 & 23.6 & 0.25 & 55 & 3.4 \\
\hline Pylypets & Pylypets & 44.2 & 854 & 32.7 & 0.25 & 55 & 3.4 \\
\hline Golyatynka & Maydan & 86 & 790 & 24.6 & 0.26 & 53 & 3.6 \\
\hline Latorytsia & Pidpolozzya & 324 & 720 & 28.7 & 0.28 & 66 & 3.4 \\
\hline
\end{tabular}

\footnotetext{
1 a.s.l. - above sea level
} 


\begin{tabular}{|c|c|c|c|c|c|c|c|}
\hline River & Hydrological gauge & 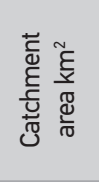 & 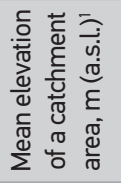 & 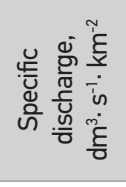 & 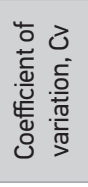 & 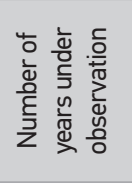 & 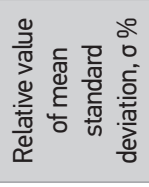 \\
\hline \multirow{3}{*}{ Latorytsia } & Svalyava & 680 & 700 & 21.7 & 0.29 & 51 & 4.1 \\
\hline & Chop & 2,870 & 760 & 12.5 & 0.51 & 55 & 6.9 \\
\hline & Mukacheve & 1,360 & 310 & 19.5 & 0.31 & 66 & 3.8 \\
\hline Vicha & Nelipyno & 241 & 570 & 27.7 & 0.27 & 56 & 3.6 \\
\hline Stara & Znyatsevo & 224 & 300 & 10.1 & 0.38 & 61 & 4.9 \\
\hline \multirow{3}{*}{ Uzh } & Zhornava & 286 & 670 & 23.2 & 0.26 & 61 & 3.3 \\
\hline & Zarichne & 1,280 & 560 & 16.4 & 0.25 & 66 & 3.1 \\
\hline & Uzhgorod & 1,970 & 530 & 14.9 & 0.27 & 66 & 3.3 \\
\hline Turya & Simer & 464 & 540 & 20.0 & 0.31 & 56 & 4.1 \\
\hline \multicolumn{8}{|c|}{ The Prut and Siret basins } \\
\hline \multirow{4}{*}{ Prut } & Vorokhta & & 1,500 & 41.1 & 0.27 & 35 & 4.6 \\
\hline & Tatariv & 366 & 1,200 & 20.9 & 0.26 & 53 & 3.6 \\
\hline & Yaremche & 597 & 990 & 21.0 & 0.28 & 63 & 3.5 \\
\hline & Chernivtsi & 6,890 & 450 & 10.6 & 0.29 & 68 & 3.5 \\
\hline Kamyanka & Dora & & & 19.5 & 0.38 & 66 & 4.7 \\
\hline Chornyava & Lyubkivtsi & & & 4.80 & 0.42 & 28 & 7.9 \\
\hline Cheremosh & Usteriky & 1,500 & 1,100 & 18.6 & 0.25 & 55 & 3.4 \\
\hline Bilyi Cheremosh & Yablunytsia & 552 & 1,200 & 17.1 & 0.38 & 55 & 5.1 \\
\hline Chorn. Cheremosh & Verkhovyna & 657 & 1,200 & 21.5 & 0.37 & 55 & 5.0 \\
\hline Iltsya & Iltsi & & & 19.4 & 0.29 & 53 & 4.0 \\
\hline Putyla & Putyla & 181 & 960 & 14.2 & 0.34 & 49 & 4.9 \\
\hline Siret & Storozhynets & 672 & 590 & 9.90 & 0.39 & 60 & 5,0 \\
\hline \multicolumn{8}{|c|}{ The Dniester basin } \\
\hline \multirow{2}{*}{ Dniester } & Strilky & 384 & 620 & 13.6 & 0.26 & 55 & 3,5 \\
\hline & Sambir & 850 & 570 & 13.1 & 0.4 & 67 & 4,9 \\
\hline \multirow{2}{*}{ Stryi } & Matkiv & 106 & 860 & 26.8 & 0.26 & 58 & 3,4 \\
\hline & Zavadivka & 740 & 780 & 21.1 & 0.2 & 51 & 2,8 \\
\hline Slavska & Slavske & 76.3 & 860 & 24.4 & 0.24 & 59 & 3,1 \\
\hline \multirow{2}{*}{ Orava } & Svyatoslav & 204 & 860 & 17.9 & 0.4 & 68 & 4,9 \\
\hline & Yasenytsia & & & 20.4 & 0.18 & 30 & 3,3 \\
\hline Stryi & Verkh. Synevydne & 2,400 & 760 & 17.6 & 0.27 & 62 & 3,4 \\
\hline Opir & Skole & 733 & 820 & 18.8 & 0.27 & 56 & 3,6 \\
\hline \multirow{2}{*}{ Svicha } & Myslivka & 201 & 1,200 & 27.1 & 0.29 & 58 & 3,8 \\
\hline & Zarichne & 1,280 & 730 & 19.7 & 0.38 & 59 & 4,9 \\
\hline Sukel & Tysiv & 138 & 770 & 22.6 & 0.52 & 54 & 7,1 \\
\hline Luzhanka & Goshiv & 146 & 660 & 16.5 & 0.36 & 64 & 4,5 \\
\hline \multirow{2}{*}{ Limnytsya } & Osmoloda & 203 & 1,200 & 33.9 & 0.2 & 56 & 2,7 \\
\hline & Perevozets & 1,490 & 760 & 15.2 & 0.43 & 59 & 5,6 \\
\hline Chechva & Spas & 269 & 820 & 18.7 & 0.32 & 57 & 4,2 \\
\hline \multirow{2}{*}{$\begin{array}{l}\text { Bystrytsia- } \\
\text { Nadvirnyanska }\end{array}$} & Pasichna & 482 & 1,000 & 22.2 & 0.52 & 56 & 6,9 \\
\hline & Cherniyiv & 679 & & 16.0 & 0.33 & 29 & 6,1 \\
\hline Vorona & Tysmenytsia & 657 & & 7.40 & 0.41 & 51 & 5,7 \\
\hline \multirow{2}{*}{$\begin{array}{l}\text { Bystrytsia - } \\
\text { Solotvynska }\end{array}$} & Guta & 112 & 1,100 & 28.0 & 0.3 & 64 & 3,8 \\
\hline & Ivano-Frankivsk & 777 & & 13.6 & 0.39 & 29 & 7,2 \\
\hline
\end{tabular}


annual flow will be representative if it does not exceed $5 \%$.

In general, $89 \%$ of the involved hydrometric stations provided the monitoring data for observation periods from 50 to 68, and the rest, from 28 to 35 years.

Analysis of relative values $(\sigma)$ of the mean river runoff demonstrated their variation mostly from 2.6 to $5 \%$ (Table 1). Their greatest values (up to $\pm 7.9 \%$ ) are inherent to hydrometric stations on those rivers that have a relatively short series of water runoff observations. The average relative values of SD for the mean annual river runoff over the entire territory of the Ukrainian Carpathians is equal to $4.2 \%$, corresponding to the absolute deviation of specific discharge $\pm 0.85 \mathrm{dm}^{3} \cdot \mathrm{s}^{-1} \cdot \mathrm{km}^{-2}$.
Thus, the accuracy of the calculation of the mean annual river runoff of the Ukrainian Carpathians is high and the data obtained are reliable for practical use.

The coefficient variation $C_{v}$ of the mean annual river runoff throughout the Ukrainian Carpathians is varying from 0.18 to 0.52 . The lowest variability $\left(C_{v}=\right.$ $0.18 \div 0.30)$ is inherent to the rivers with a high specific discharge from 20 to $38 \mathrm{dm} 3 \cdot \mathrm{s}^{-1} \cdot \mathrm{km}^{-2}$, and the largest $\left(C_{v}=0.30 \div 0.52\right)$ is inherent to the rivers with the mean annual runoff from 5 to $20 \mathrm{dm} 3 \cdot \mathrm{s}^{-1} \cdot \mathrm{km}^{-2}$.

Such spatial changes in the mean annual river runoff and their coefficient variation are caused by the altitude position of catchment basins and slopes of their surface (Fig. 1-2).

Fig. 1. Relationship of the specific discharge water in the rivers of the Ukrainian Carpathians with the mean altitude of catchment basins

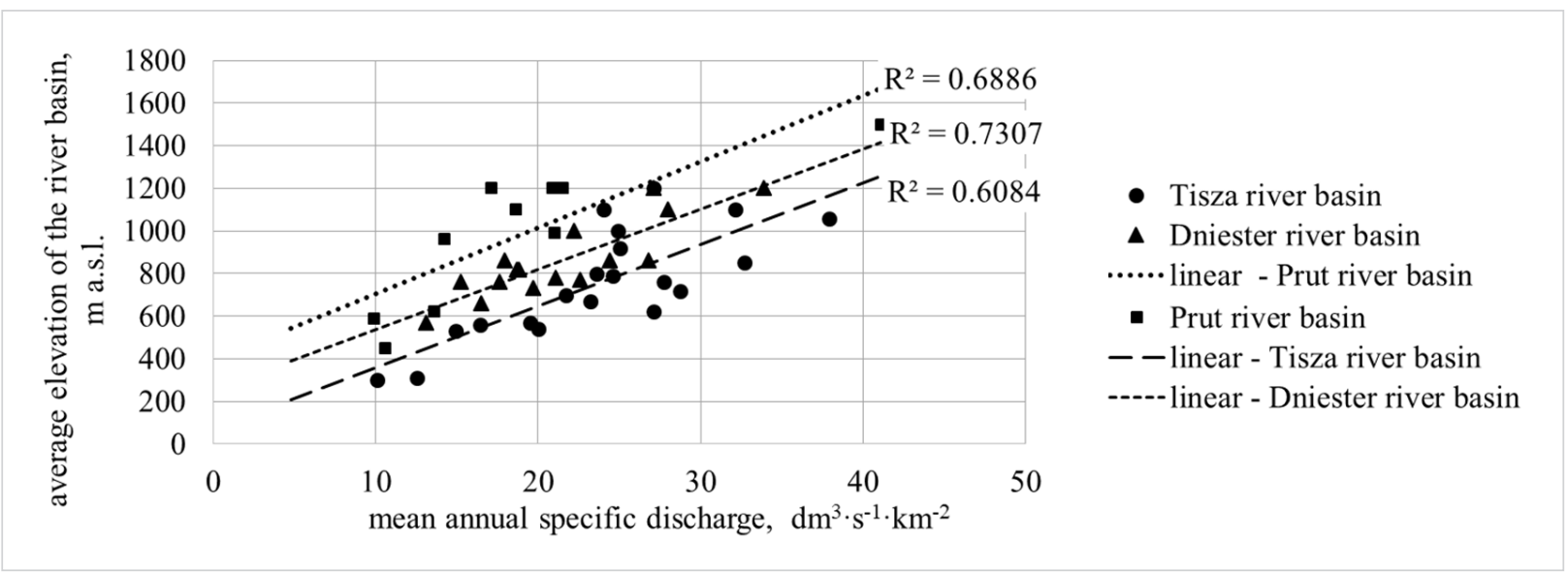

Fig. 2. Relationship between the mean altitude of the river catchment areas in the Carpathian region and their mean slopes

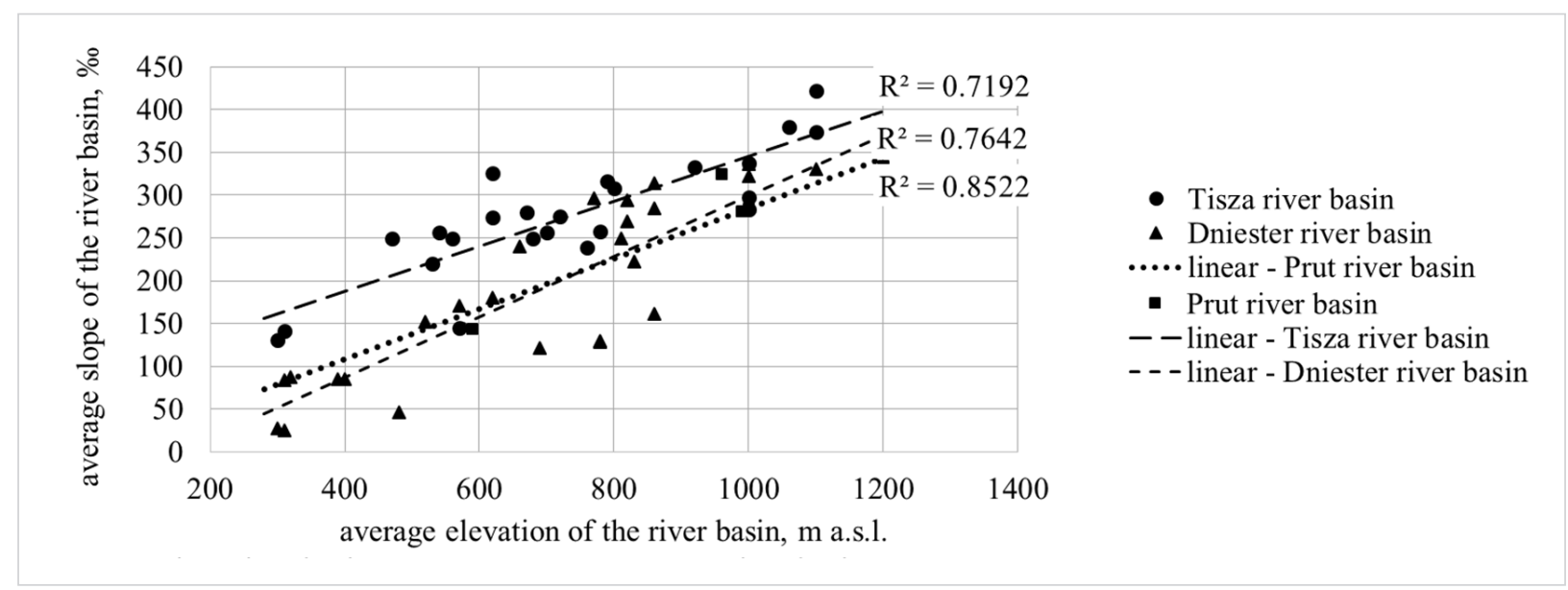


Relationship between the mean annual river runoff and the mean altitude of their catchment basins, as well as the mean altitude and their mean inclination, are detailed for the Tisza river basin, the mountain part of the rivers Prut and Siret within the Ukrainian territory and the right-bank mountain tributaries of the Dniester (Fig.1-2). The value of interdependence between the two variates is high. The correlation coefficients are within $r=0.78 \div 0.92$. Overall, a clear increase of the specific discharge water is observed with a rising catchment basin mean altitude (Fig. 1), and the higher the catchment basins, the greater their mean slopes (Fig. 2).

Each river basin has its characteristics of the river runoff power and intensity. The largest mean annual river runoff of the Tisza basin and the lowest of the Prut and Siret river basins have the same average altitude of the catchment area. The Dniester catchment basins occupy a middle position (Fig. 1). The differences between the river runoff at a certain altitude for the river basins are approximately $5.0 \mathrm{dm}^{3} \cdot \mathrm{s}^{-1} \cdot \mathrm{km}^{-2}$.

As to the relationship between the mean altitude of catchment basins of the Carpathian rivers and their mean slope, at all altitudes in the Tisza basin, there are the largest mean slopes of catchment basins, as compared with the Prut and Siret river basins and also with the right-bank tributaries of the Dniester river.

All the identified regularities are taken into account for the spatial generalisation of the mean annual river runoff.

\section{Algorithm for mapping of the mean annual river runoff and its reliability assessment}

Analysis of comprehensive hydrological and cartographic information is necessary for the runoff mapping by the means of GIS since the density and uniformity of point distribution, as well as an adequate preliminary data, are essential to compile the basis of an electronic map. The need for GIS involvement (Andrianov, 2003; Kashchavtseva et al., 2011) is explained by the validity of all received results and efficiency when settling many hydrological problems. The software application ArcGIS10, the most common software product for GIS mapping, was used in the work for implementing such tasks (Spatial Analyst Tutorial ESRI, 2010).
The orientation of river runoff contour lines should conform to the general geographic trends in changes of hydrological characteristics, topography, climate and other physical and geographical features of the territory (Klimenko, 2009).

Considering all above-mentioned approaches allowed us to provide the river runoff mapping of the Carpathian region with the resulting provision that foresees several following stages:

Basic/preparatory. At this stage, one should assess the completeness of hydrological data, erform calculations of mean annual runoff characteristics, create the necessary preparatory shape-files that would contain basic information about hydrography, hydrological gauges, relief, precipitation, and the steepness of slopes.

Modelling of river basins. At this stage, it is expected to outline the catchment contours along the rivers, as well as by hydrological gauges. Based on such modelling, the new shape-files are created: contours of catchment basins, and centroids of catchment basins.

Selecting the methods of interpolation and designing the contours lines.

It is necessary to evaluate the results of interpolation methods and to choose the one among them in order to describe correctly the runoff distribution over the territory. As a result, the new shape-file is created: contour lines of the mean annual rivers runoff.

At the basic preparatory stage of the mean annual river runoff mapping in the Ukrainian Carpathians, some significant difficulties, associated with a lack of control points, came into existence. To execute the reliable map, it is essential to get data from all the basin parts, and even from those outside Ukraine. So, the evidence from 94 gauging stations in Ukraine (22 in the Tisza basin, 61 in the Dniester basin, 11 in the Prut and Siret basins) and outside of Ukraine ( 5 in Slovakia, 6 in Hungary, and 4 in Romania in the Tisza basin; 4 in Romania in the Prut and Siret basins; and 8 in Poland in the river San basin) were used for mapping of the mean annual river runoff.

A necessary condition for runoff mapping is the determination of the catchment area for each gauging station. The definition of catchment basin contours is 
executed by the algorithm, which provides processing of digital relief models (SRTM HydroSHEDS; $83 \mathrm{~m}$, 1:50000-1:100000) by hydrological modelling functions that are built into the Spatial Analyst-Hydrology modulus (Glotka, 2014).

To create a map of hydrological characteristics, the centre of gravity or centroids of catchment basins should be determined (Shevchuk et al., 2014). The software application ArcGIS and its interpolation method "Natural neighbour" were used at mapping the spatial distribution of the mean annual river runoff for the Carpathians (Polovko et al., 2004; Tikunov, 2004). Boundaries between the classes are established in such points where the best grouping of the closest values in each of class and the maximum difference in values between the classes are achieved. The user assigns the number of classes. This interpolation method is based on the weighted averaged values and was used in our studies. Based on the interpolation method, the contours lines of the mean annual river runoff are created by the contour function. This function allows drawing the contour lines for the mean annual runoff for the whole set of data, and the interval of runoff values between them prescribes the distance between the contour lines. The resulting map is relevant and the most comprehensive and contemporary for the rivers in the Carpathian region (Fig. 3).

As a result of analysis of the created map of the mean annual river runoff of the Carpathian region, the reliability assessment was made by the following approaches. First, it was done according to the relationship between the actual values in the hydrological observing station, and those values are plotted on the map (Fig. 4). It should be pointed out that the mean annual river

Fig. 3. Map of the specific discharge in the Ukrainian Carpathian region

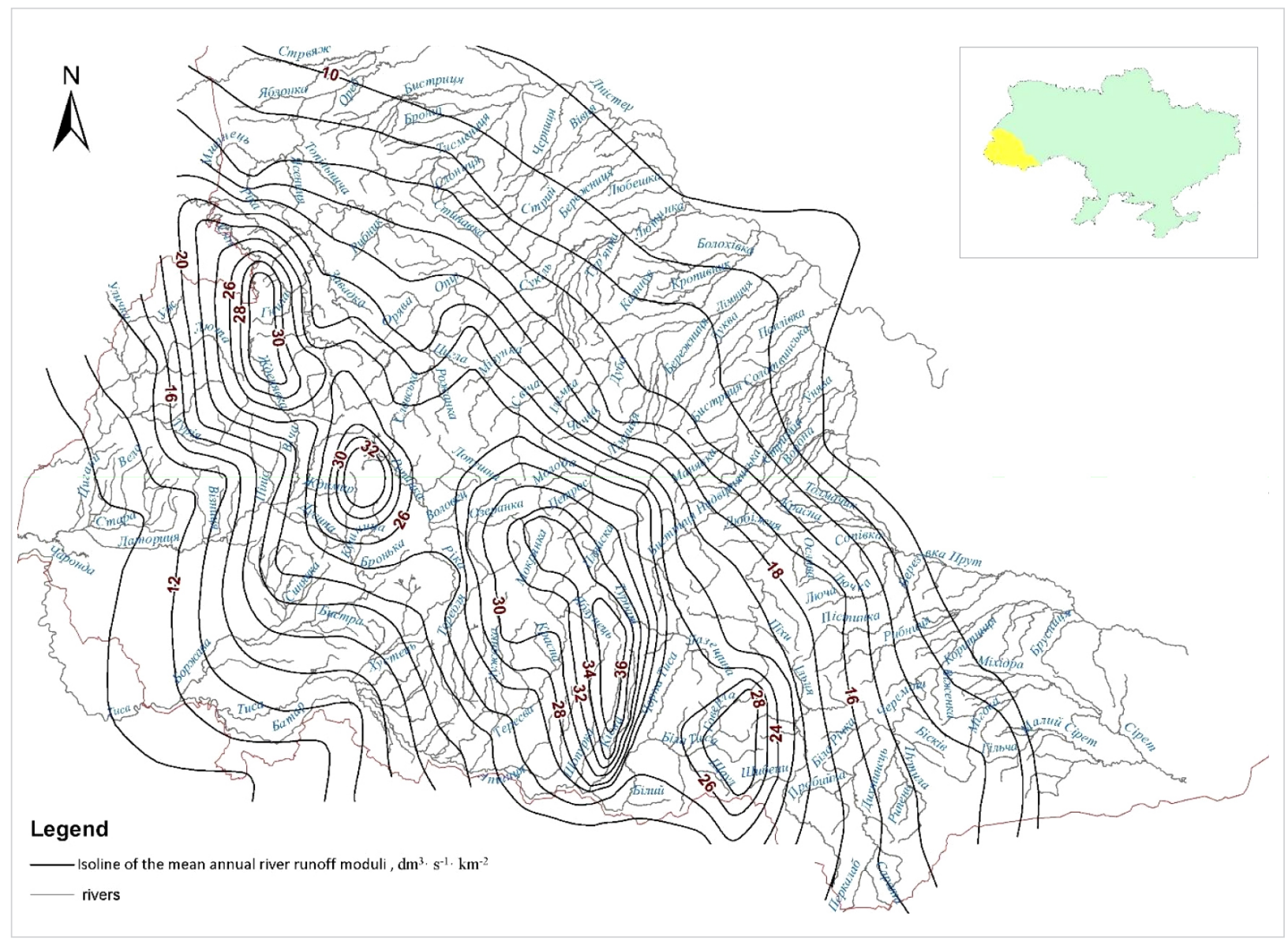


Fig. 4. Relationship between the calculated and the mapped values of the mean annual river runoff of the Ukrainian Carpathian region

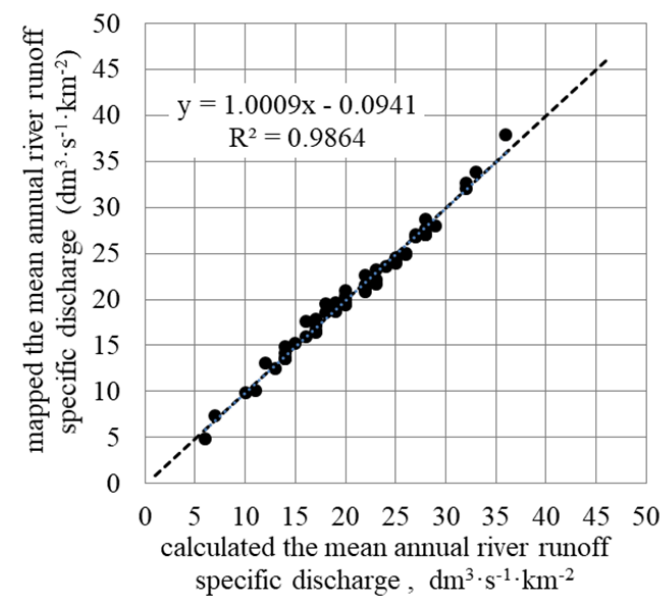

runoff was verified not only by the data obtained from the hydrological observing station involved for mapping but also by those data that were not taken for mapping (short series of observation, little catchment basins).

In this case, there is a close relationship between the given values, and the correlation coefficient appears as $r=0.993$. Moreover, the relationship line coincides with the line of equal values (regression equation, Fig. 4). The deviation of the calculated and the mapped values of the mean annual river runoff is within the limits of the SD for the calculated values.

Second, the reliability assessment of the created map was performed by correlating analysis of the specific discharge and spatial precipitation distribution aimed at controlling the water-balance relationship preservation throughout the river basins. Spatial distribution of the mean annual river runoff in general should to some extent repeat precipitation distribution over its territory.

In conditions of the Ukrainian Carpathian Mountains relief, the spatial distribution of precipitation has a multidimensional nature, is explained by the features of mesoscale circulation and depends on the spatial arrangement of mountain ranges. Herein, the horizontal and vertical components dominate (Balabukh et al., 2011). The lowest precipitation occurs in lowlands and foothills $(650-900 \mathrm{~mm})$. With altitude, precipitation mainly grows to $1,800 \mathrm{~mm}$. However, such regularity is broken by the feature of the mountain ranges arrangement and by the protection of certain areas from the moist airflows. Maximum annual precipitation happens in the central mountains and on the mountain range tops. On the north-eastern part of the Tisza river basin, the Carpathian Mountains form the curve, which changes the south-east direction in the area of the greatest altitude for the south direction towards Romania. Due to such a location of the mountain ranges, favourable conditions for the intensification of atmospheric precipitation are created here more frequently than in other areas (Lukianets et al., 2015; Susidko et al., 2010). The areas of the permanent orographic maxima and minima of precipitation are typical for the Ukrainian Carpathians.

The maximums of precipitation were outlined as follows: in the Tisza Basin - the upper catchment basins of the Kosovska, Teresva, Tereblya rivers (1200-1600 mm); the upper catchment basins of the Borzhava and partially the Rica (1000-1200 mm); the upper catchment basins of rivers Latorytsia and Uzh (1000-1200 mm). The mountain peaks of the Tisza Basin above 1,000 m a.bs.l. receive 1,400-1,700 $\mathrm{mm}$.

Areas with maximum precipitation are uneven by sizes and coverage areas (Balabukh et al., 2011; Sosedko, 1980; Susidko, 2002). The orographic minimum is in the upper Tisza (900-1,000 mm) since this area is partly protected by mountains from the humid airflows from the southwest (Lukianets et al., 2014).

Instead, in the mountainous part of the right bank of the Dniester, the orographic peaks are of the catchment of the Stryi and Opor, the upper reach of the Svicha, the mean part of the catchment basins of the Limnytsya and Bystrica rivers (950-1,100 mm).

In the mountainous part of the Prut basin, the largest annual precipitation is observed in the upper reaches of the Prut, partially of the Cheremosh rivers (900$1,100 \mathrm{~mm}$ ), and the smallest precipitation is observed in the upper reach of the Chornyy and the Bilyyi Cheremosh, Putila (750-850 mm). At this point, the mountain peaks are over $1,000 \mathrm{~m}$, and the precipitation amounts to 1,100-1,300 mm (Lukianets et al., 2014).

Analysis of the compiled maps of the mean annual river runoff of the Ukrainian Carpathians demonstrated that it meets the aforementioned spatial distribution of precipitation. All the above points to a fairly high 
reliability of the spatial generalisation of the mean annual river runoff of the Ukrainian Carpathians and the applicability of the developed maps for practical and scientific purposes.

\section{Analysis of territorial variability of the mean annual runoff in of the main river basins of the Ukrainian Carpathians}

Analysis of the spatial distribution of the mean annual runoff in the main river basins of the Ukrainian Carpathians showed that the rivers under study are with the most water resources in Ukraine. Its values are summarised in Table 2, which presents the mean annual river runoff by altitude zones (lowland, foothills, low-mountain terrain, mid-mountain terrain) identifying the areas with the highest river runoff. Areas of certain altitude zones and river basins with a high river runoff are shown in $\mathrm{km}^{2}$ and $\%$ concerning the whole area of the river basins (separately for the Tisza river basin, right bank of the Dniester, the Prut and Siret rivers).

The average long-term water runoff in the Tisza basin varies in the range from 10 to $38 \mathrm{dm}^{3} \cdot \mathrm{s}^{-1} \cdot \mathrm{km}^{-2}$; in the basin of the right bank of the Dniester - from 8 to $32 \mathrm{dm}^{3} \cdot \mathrm{s}^{-1} \cdot \mathrm{km}^{-2}$; and in the Prut and Siret basins from 6 to $26 \mathrm{dm}^{3} \cdot \mathrm{s}^{-1} \cdot \mathrm{km}^{-2}$.

The largest values of specific discharge in the Tisza basin are observed in the upstream of the Kosovska, Teresva, Tereblya rivers, i.e., $32-38 \mathrm{dm}^{3} \cdot \mathrm{s}^{-1} \cdot \mathrm{km}^{-2}$. Two more locations of increased runoff in the Tisza basin are situated in the upper reaches of the Rika, Borzhava, Latorytsya, and partly Uzh rivers. They compose correspondingly $30-32 \mathrm{dm}^{3} \cdot \mathrm{s}^{-1} \cdot \mathrm{km}^{-2}$ and 28-30 dm $3 \cdot \mathrm{s}^{-1} \cdot \mathrm{km}^{-2}$. At this point, the mean annual river runoff is lowered due to lowering wetting on this area. For the same reason, the river runoff in the far east of the Tisza River basin (in its upper reaches) is also slightly lowered $-25-28 \mathrm{dm}^{3} \cdot \mathrm{s}^{-1} \cdot \mathrm{km}^{-2}$. It is caused by the fact that such an area is partly protected by mountains from the south-western humid airflows. As for the Dniester river basin, the most abundant catchment basins of the upstream of the Opor, Svicha, Limnytsya and Bystrica rivers have the mean annual runoff within 25-32 $\mathrm{dm}^{3} \cdot \mathrm{s}^{-1} \cdot \mathrm{km}^{-2}$. The Siret and Prut river basins, where precipitation is lower than in the Tisza and Dniester basins, are characterised
Table 2. River runoff (specific discharge) over the main river basins in the Ukrainian Carpathians

\begin{tabular}{|c|c|c|c|}
\hline \multirow{2}{*}{$\begin{array}{l}\text { High-altitude zones and } \\
\text { river basins with a high } \\
\text { runoff }\end{array}$} & \multirow{2}{*}{$\begin{array}{c}\text { Specific } \\
\text { discharge, } \\
\mathrm{dm}^{3} \cdot \mathrm{s}^{-1} \cdot \mathrm{km}^{-2}\end{array}$} & \multicolumn{2}{|c|}{$\begin{array}{c}\text { Area of identified } \\
\text { territories }\end{array}$} \\
\hline & & $\mathrm{km}^{2}$ & $\%$ \\
\hline \multicolumn{4}{|c|}{ Tisza basin } \\
\hline Flatland & $10-15$ & 2,400 & 19 \\
\hline Foot-hills & $15-25$ & 3,800 & 30 \\
\hline Low-mountain terrain & $25-30$ & 2,700 & 21 \\
\hline $\begin{array}{l}\text { Low-mountain - upper } \\
\text { reaches of Kosovska, } \\
\text { Teresva, Tereblya, Rika, } \\
\text { Borzhava, Latorytsya }\end{array}$ & $30-38$ & 2,900 & 22 \\
\hline $\begin{array}{l}\text { Middle-mountain - upper } \\
\text { reach of Tisza river }\end{array}$ & $25-28$ & 1,000 & 8 \\
\hline \multicolumn{4}{|c|}{ Dniester basin } \\
\hline Flatland & $8-12$ & 3,500 & 28 \\
\hline Foot-hills & $12-16$ & 2,500 & 20 \\
\hline Low-mountain terrain & $16-25$ & 5,100 & 40 \\
\hline $\begin{array}{l}\text { Low-mountain - upper } \\
\text { reaches of Opor, Svicha, } \\
\text { Limnytsya and Bystrica }\end{array}$ & $25-32$ & 1,500 & 12 \\
\hline \multicolumn{4}{|c|}{ Prut and Siret basins } \\
\hline Flatland & $6-10$ & 3,200 & 42 \\
\hline Foot-hills & $10-15$ & 1,900 & 26 \\
\hline $\begin{array}{l}\text { Low-mountain and } \\
\text { middle-mountain - the } \\
\text { upper reach of Prut, } \\
\text { Cheremosh }\end{array}$ & $15-26$ & 2,400 & 32 \\
\hline
\end{tabular}

Note. Areas of certain altitude zones and river basins with a high runoff are given in \% to the entire area of river basins

by lower river runoff with maximum values of 15$25 \mathrm{dm}^{3} \cdot \mathrm{s}^{-1} \cdot \mathrm{km}^{-2}$ in the upstream of the Prut and Cheremosh basins.

The river runoff on the southwest slope of the Ukrainian Carpathians (the Tisza Basin) is greater than on the north-eastern slope (the Dniester, Prut and Siret basins). At this point, the catchment basins with an 
increased river runoff also occupy most of the areas. So, if you take the value of specific discharge of $15 \mathrm{dm}^{3} \cdot \mathrm{s}^{-1} \cdot \mathrm{km}^{-2}$ and more, then it could be observed not only in the mid-mountains and low-mountains but also in the foothills. The areas with such a river runoff cover almost $80 \%$ of the Tisza river basin (Table 2). In the basin of the Dniester right bank, the areas with a river runoff of $15 \mathrm{dm}^{3} \cdot \mathrm{s}^{-1} \cdot \mathrm{km}^{-2}$ and more come to $52 \%$, and in the basins of the Prut and Siret rivers to $32 \%$ (Table 2).

The relationship between the specific discharge of the Carpathian rivers within Ukraine and coefficients of their variation for a long-standing period (Table 1 , Fig. 5) with correlation ratio $r=0.64$ demonstrates the territorial variability of the runoff.

Fig. 5. The relationship between the specific discharge from the basins and their coefficients of variation

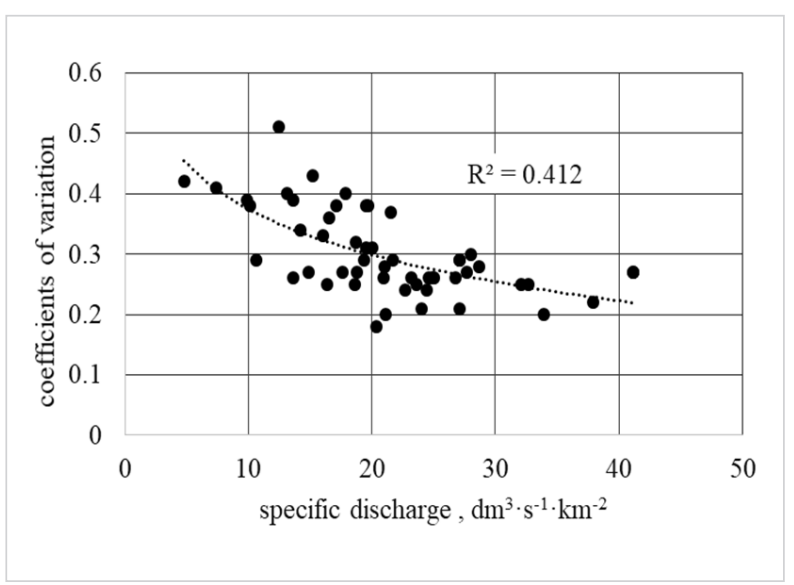

The river basins with average annual water runoff modules of $20-40 \mathrm{dm}^{3} \cdot \mathrm{s}^{-1} \cdot \mathrm{km}^{-2}$ have a long-term variation on average $\pm 20-30 \%$ of the normal, and with the modules, less than $20 \mathrm{dm}^{3} \cdot \mathrm{s}^{-1} \cdot \mathrm{km}^{-2}$ the

\section{References}

GIS by ESRI 2010. «Spatial Analyst Tutorial» ESRI. http://help. arcgis.com/en/arcgisdesktop/10.0/pdf/spatial-analyst-tutorial.pdf.

Global Data Explorer / U.S. Geological Survey. http://gdex. cr.usgs.gov/gdex/.

Lukianets O. and Balabukh V. (2014) Water flow of rivers in modern and expected climate changes in Basin Tisza (within the lim- variation gradually increases to $\pm 40-50 \%$ if compare with the normal. The river runoff with a $1 \%$ probability of exceeding is mainly 2.0-2.5 times higher of the average annual values.

\section{Conclusions}

The map of the mean annual river runoff of the Ukrainian Carpathian region is based on the runoff observational data at the hydrometric network of the rivers of the Ukrainian Carpathian and adjacent basins bordering the studied area for the period from the beginning of observations to 2012 . About $90 \%$ of hydrometric stations have the observation period from 50 to 68 years, so the input data of the mean annual river runoff for mapping are stable with the relative value of the standard deviation on the average $\pm 4.2 \%$.

The ArcGIS software may be applicable for the mean annual river runoff mapping with the aim to provide high accuracy results.

The analysis of the constructed map showed that the obtained features of territorial variability of runoff values in the main river basins of the Ukrainian Carpathians (Tisza, Right Bank of the Dniester, Prut and Siret) well corresponding to their formating conditions such as water-balance ratio and the water content degree.

This indicates the reliability of spatial generalisation of the mean annual river runoff of the Ukrainian Carpathian region. Therefore, the created detailed map of the mean annual river runoff can be used for scientific and applied purposes for water resources assessment of individual basins or entire regions of the Ukrainian Carpathians, even unstudied before from the hydrological standpoint. It can also be used for calculating the hydropower potential of certain Carpathian rivers. its of Ukraine). Proceedings XXVIth Conference of the Danube Countries on Hydrological Forecasting and Hydrological Bases of Water Management. Deggendorf, Germany, 109-112.

Lukianets O. and Obodovskyi, I. (2015) Spatial, Temporal and Forecast Evaluation of Rivers' Streamflow of the Drainage Basin of the Upper Tisa under the Conditions of Climate Change. Scientific Journal: ENVIRONMENTAL Research, Engineering and 
Management. Kaunas: KTU, Lithuania No. 71(1): 36-46. https:// doi.org/10.5755/j01.erem.71.1.10286. https://doi.org/10.5755/ j01.erem.71.1.10286

Mean Annual Surface Runoff 1950-2000. http://atlas.gwsp. org/index.php?option=com_content\&task=view\&id=96.

Ven Te Chow, Maidment D. R. and Mays L. W. (Ed.) (1988) Applied hydrology. New York: McGraw-Hill, USA: 572. http:// ponce.sdsu.edu/Applied_Hydrology_Chow_1988.pdf.

Andrianov V. (2003) Чрезвычайные ГИС (Extraordinary GIS). ArcView - Современные геоинформационные технологии. Чрезвычайные Ситуации. №3. C.79-85. https://www.esri-cis. ru/news/arcreview/detail.php?ID=2114\&SECTION_ID=55.

Balabukh V. A. and Lukianets O. I. (2011) Характер багаторічних змін атмосферних процесів та стоку в басейнах річок Пруту та Сірету (в межах України) у теплий період року (Character of long-term changes of atmospheric processes and flow in rivers Basins of Prut and Siret (within Ukraine) in the warm season) Науковий вісник Чернівецького університету: збірник наукових праць. Чернівці. Вип. 587-588: Географія. С. 70-81. https://www.researchgate.net/ publication/326318867.

Denisova Yu. I. and Perevoshchikov A. А. (2009) Построение прогнозной модели зоны затопления средствами ГИСтехнологий (Creation of the forecast model of flood zone by GIS technologies). Вестник Удмуртского университета. Вып. 1. C.171-178. https://cyberleninka.ru/article/n/postroenie-prognoznoy-modeli-zony-zatopleniya-pos-kizner-sredstvami-gis-tehnologiy.

Doganovskiy A. M. and Orlov V. G. (2011) Сборник задач по определению основных характеристик водных объектов суши (практикум по гидрологии) (Casebook for definition of the basic characteristics of water objects located on land (workshop on hydrology)). Изд-во РГГМУ, Санкт-Петербург. 315 с. https://www.twirpx.com/file/1151351/

Glotka D. (2014) Удосконалення карти гідрографічного розмежування території України на основі SRTM HydroSHEDS (Improvement of the map of hydrographic delineation of territory of Ukraine based on SRTM HydroSHEDS). Фізична географія та геоморфологія Вип. 3 (75). с. 114-117.

Horbachova L. O. (2010) Просторове узагальнення норм річного стоку води (The space generalization of the normal annual runoff). Гідрологія, гідрохімія і гідроекологія. Т. 18. C. 107-112. http://nbuv.gov.ua/UJRN/glghge_2010_18_15. https://doi.org/10.3846/coactivity.2010.41

Kashchavtseva A.Yu. and Shipulin V. D. (2011) Моделирование речных бассейнов средствами Arc GIS 9.3 (Modeling river basins using Arc GIS 9.3). Ученые записки ТНУ им. В. И. Вернадского
Серия «География» Том 24(63). №3. Симферополь: ТНУ. С.8593. https://www.twirpx.com/file/1377004/.

Klibyshev K. P. and Goroshkov I. F. (1970) Гидрологические расчеты (Hydrological calculations). Л.: Гидрометеоиздат. 460 c. Klimenko D. E. (2008) Методика расчета максимального весеннего стока малых рек Среднего Приобья и северного склона Сибирских Увалов (Methods of calculating the maximum spring runoff of small rivers of the Middle Priob and the northern slope of the Siberian Uvalov). Географический вестник Пермского государственного университета. https:// cyberleninka.ru/article/n/metodika-rascheta-maksimalnogo-vesennego-stoka-malyh-rek-srednego-priobya-i-severnogo-sklona-sibirskih-uvalov.

Kocherin D. N. (1932) Вопросы инженерной гидрологии (Task of engineering hydrology). НКТП СССР, М. 136 C.

Komlev A. М. (2002) Закономерности формирования и методы расчётов речного стока (Laws of formation and methods of river runoff calculations). Пермь: Изд-во Пермского государственного университета. 163 c. https://www.rfbr.ru/ rffi/portal/books/o_27136.

Konovalenko O. S., Dutko V. O. and Vasilenko E. V. (2012) Просторовий розподіл максимального стоку води весняного водопілля річок басейну Стир (Spatial distribution of maximal spring runoff of the Styr Basin Rivers). Гідрологія, гідрохімія і гідроекологія. Т. 1(26). С.69-75. http://nbuv.gov.ua/UJRN/ glghge_2012_1_10.

Luchsheva A. А. (1976) Практическая гидрология (Practical hydrology) Л.: Гидрометеоиздат. 440 с.

Melnikova T. N. (2004) Норма годового стока рек северозападного Кавказа и особенности ее территориального распределения (The normal of annual runoff of rivers of the Northwest Caucasus and features of its territorial distribution). Материалы шестой Международной конференции. Том первый. СевероКавказский государственный технический университет, Ставрополь, 2004. С. 177-179.

Paton B. E., Shpak A. P., Rudenko L. G. et al. (2007) Національний атлас України (National Atlas of Ukraine). Київ: Державне науково-виробниче підприємство «Картографія», 440 с. http://www.ukrmap.com.ua.

Polovko A. M. and Butusov P. N. (2004) Интерполяция. Методы и компьютерные технологии их реализации (Interpolation. Methods and computer technology of their implementation) Санкт-Петербург: БХВ-Петербург. 320 с.

Shevchuk S. A., Vyshnevskyy V. I. and Babiy P. O. (2014) Уточнення гідрографічних характеристик річок з використанням методів ДЗ3 (Clarification of the hydrographic 
characteristics of rivers using remote sensing techniques). Вісник геодезії та картографії, № 5 (92). С. 29-32. http:// nbuv.gov.ua/UJRN/vgtk_2014_5_12.

Sokolovskiy D. D. (1968) Речной сток. Л.: Гидрометеоиздат. $540 \mathrm{c}$.

Sosedko M. N. (1980) Особенности пространственной структуры полей осадков на территории Украинских Карпат (Features of the spatial structure of precipitation fields on the territory of the Ukrainian Carpathians). Тр.УкрНИГМИ. Вып. 180. C. 81-85.

Susidko M. М. (2002) Карпати-найбільшпаводконебезпечний регіон України (The Carpathians are the most flood dangerous region of Ukraine). Материали міжнародної конференції «Гори та люди». Том 2. С.158-161.
Susidko M. M. and Lukianets O. I. (2010) Карпати - паводконебезпечний регіон України. Комплексна басейнова система прогнозування паводків у Закарпатті: методична та технологічна база їі складових (The Carpathians - flood danger region of Ukraine. Basin runoff forecasting systen in Zakarpattya: methodical and technological basis of its components). Київ. 63 c.

Tikunov V. S. (2004) Основы геоинформатики (Fundamentals of Geoinformatics). М.: Изд. Центр «Академия». 352 c. http:// www.geokniga.org/bookfiles/geokniga-tikunov-vs-osnovygeoinformatiki-v-2-h-kn-kn-1-m-ic-akademiya-2004.pdf.

Zaykov B. D. and Belinkov S. Yu. (1937) Средний многолетний сток СССР (Average long-term runoff of the USSR). Труды ГГИ, вып. 2. 78 с. 